\title{
Arqueología del amor: la representación de Afrodita y de Eros en el pensamiento antiguo*
}

Archeology of love: the representation of Aphrodite and Eros in ancient thought

\author{
Por: Lidia Raquel Miranda* \\ CONICET/IDEAE, FCH, UNLPam \\ Santa Rosa, La Pampa \\ Email: mirandaferrari@cpenet.com.ar / mirandaraq@gmail.com \\ ORCID: 0000-0002-7744-0210 \\ Fecha de recepción: 31/01/2019 \\ Fecha de aprobación: 11/03/2019
}

\section{Resumen:}

Conocida es la figura de Afrodita (Venus entre los latinos), diosa griega del amor y la belleza, una de las doce grandes deidades del panteón olímpico. Ella encarna la fuerza y la omnipotencia creadora del deseo amoroso, al cual se hallan sometidos todos los seres vivos sin distinción: humanos, animales e, incluso, los mismos dioses. Seductora, en ocasiones temible, es una de las fuerzas fundamentales del mundo, como apunta la tradición más conocida relacionada con su nacimiento: según Hesíodo, Afrodita nació de Urano, cuando su hijo Cronos, después de mutilarlo, arrojó al mar sus genitales. La simiente del dios castrado fecundó la espuma de las olas y en ellas engendró a esta diosa de radiante belleza, a cuyo paso nacían las flores. Dicha historia explica el significado de su nombre pues aphros significa 'la espuma'. Mantuvo relaciones amorosas con muchos dioses y también con mortales, aunque su esposo, elegido por

\footnotetext{
* Las reflexiones de este artículo se enmarcan en la producción del PICT 20160534 "Cuerpo y metáfora en la construcción ideológica de las instituciones jurídicas y políticas", del cual soy investigadora responsable. Puntualmente, el trabajo se relaciona con las investigaciones acerca de la representación de personajes (históricos, míticos y literarios) que llevo adelante en el contexto de dicho proyecto.

* Doctora en Letras por la Universidad Nacional de Tucumán (Argentina). Investigadora Independiente del Consejo Nacional de Investigaciones Científicas y Técnicas (CONICET, Argentina). Docente de Literatura Española I y Lengua Española en la Facultad de Ciencias Humanas, Universidad Nacional de La Pampa (Argentina).
} 


\section{Arqueología del amor: la representación de Afrodita y de Eros en el pensamiento antiguo.}

Zeus, era Hefestos, el dios del fuego. De sus amores con Ares (el Marte de los romanos), dios de la guerra, nació Eros, el dios del amor.

Eros (Cupido entre los romanos), que simboliza el deseo sensual, es el dios griego responsable de la atracción sexual, el amor y el sexo, venerado también como un dios de la fertilidad. Según Hesíodo, es una de las fuerzas primordiales que nace del Caos. Según otras versiones, como señalamos antes, es hijo de Ares y de Afrodita. De acuerdo con el mito que ofrece El banquete de Platón, Eros fue concebido por Poros (el Recurso) y Penía (la Pobreza) en el cumpleaños de Afrodita. A partir de la tradición iniciada por Eratóstenes, Eros rige fundamentalmente el amor entre hombres, mientras que Afrodita lo hace sobre el amor entre hombres y mujeres. En imágenes tardías, se lo representa como un niño travieso, muchas veces con los ojos vendados, equipado con un arco y flechas con las que atraviesa los corazones de los enamorados.

En este trabajo nos ocuparemos de rastrear -aunque sin pretensión de exhaustividad- las figuras de Afrodita y de Eros en los episodios míticos más conocidos o relevantes de la literatura clásica, en atención a dos líneas principales de interpretación de ambos dioses: las referidas al discurso amoroso y/o erótico que surge en torno a ellos y sus acciones y las vinculadas con el cuerpo y sus características. Palabras clave: Amor, Afrodita, Eros, Antigüedad

\section{Abstract:}

Known is the figure of Aphrodite (Venus among Latins), Greek goddess of love and beauty, one of the twelve great deities of the Olympic pantheon. She embodies the force and creative omnipotence of loving desire, to which all living beings are subject without distinction: humans, animals and even the gods themselves. Seductive, sometimes fearsome, is one of the fundamental forces of the world, as pointed out by the best-known tradition related to his birth: according to Hesiod, Aphrodite was born of Uranus, when his son Cronos, after mutilating him, threw his genitals into the sea. The seed of the castrated god fecundated the foam of the waves and in them engendered this goddess of radiant beauty, at whose passage the flowers were born. This story explains the meaning of his name because aphros means 'foam'. He 
maintained loving relationships with many gods, and also with mortals, although her husband, chosen by Zeus, was Hephaestus, the god of fire. From his love affair with Ares (the Mars of the Romans), god of war, was born Eros, the god of love.

Eros (Cupid among the Romans), which symbolizes sensual desire, is the Greek god responsible for sexual attraction, love and sex, also revered as a god of fertility. According to Hesiod, it is one of the primordial forces born of Chaos. According to other versions, as we pointed out before, he is the son of Ares and Aphrodite. According to the myth that Plato's Banquet offers, Eros was conceived by Poros (the Resource) and Penía (Poverty) on the birthday of Aphrodite. Starting from the tradition initiated by Eratosthenes, Eros fundamentally governs love between men, while Aphrodite does it over love between men and women. In later images, he is shown as a mischievous child, often blindfolded, equipped with a bow and arrows that pierces the hearts of lovers.

In this paper, we will investigate, although without pretension of exhaustiveness, the figures of Aphrodite and Eros in the most known or relevant mythical episodes of classical literature, in attention to two main lines of interpretation of both gods: those referring to speech amorous and / or erotic that arises around them and their actions and those related to the body and its characteristics.

Keywords: Love, Aphrodite, Eros, Antiquity

\section{Cómo citar este artículo:}

APA: Miranda, L. R. (2019). Arqueología del amor: la representación de Afrodita y de Eros en el pensamiento antiguo. Nuevo Itinerario, 14 (1), 29-57. Recuperado de: (agregar dirección web)

En la base del problema de conocimiento que nos hemos planteado en este artículo -es decir, la representación del amor en el pensamiento antiguo- están las palabras y las cosas: "Si bien es cierto que la ciencia en algún sentido construye su objeto, no lo es menos que sin el suelo de las cosas y las expresiones que las nombran no existiría la ciencia" (Castañares, 2014, p. 15). En efecto, en los albores de la 


\section{Arqueología del amor: la representación de Afrodita y de Eros en el pensamiento antiguo.}

reflexión semiótica, mucho antes del surgimiento de la disciplina moderna, los fenómenos 'significativos' y las palabras que los nombraban también estaban conectados. En tal sentido, los nombres e imágenes de Afrodita y de Eros tienen, en el seno de las obras antiguas, un carácter sígnico y múltiples connotaciones que merecen ser recuperados para comprender los alcances de su sentido y referencia.

Conocida es la figura de Afrodita (Venus entre los latinos), diosa griega del amor y la belleza, una de las doce grandes deidades del panteón olímpico. Ella encarna la fuerza y la omnipotencia creadora del deseo amoroso, al cual se hallan sometidos todos los seres vivos sin distinción: humanos, animales e, incluso, los mismos dioses. Seductora, en ocasiones temible, es una de las fuerzas fundamentales del mundo, como apunta la tradición más conocida relacionada con su nacimiento: según Hesíodo, Afrodita nació de Urano, cuando su hijo Cronos, después de mutilarlo, arrojó al mar sus genitales. La simiente del dios castrado fecundó la espuma de las olas y en ellas engendró a esta diosa de radiante belleza, a cuyo paso nacían las flores. Dicha historia explica el significado de su nombre pues aphros significa 'la espuma'. Mantuvo relaciones amorosas con muchos dioses y también con mortales, aunque su esposo, elegido por Zeus, era Hefestos, el dios del fuego. De sus amores con Ares (el Marte de los romanos), dios de la guerra, nació Eros, el dios del amor.

Eros (Cupido entre los romanos), que simboliza el deseo sensual, es el dios griego responsable de la atracción sexual, el amor y el sexo, venerado también como un dios de la fertilidad. Según Hesíodo, es una de las fuerzas primordiales que nace del Caos. Según otras versiones, como señalamos antes, es hijo de Ares y de Afrodita. De acuerdo con el mito que ofrece El banquete de Platón, Eros fue concebido por Poros (el Recurso) y Penía (la Pobreza) en el cumpleaños de Afrodita. A partir de la tradición iniciada por Eratóstenes, Eros rige fundamentalmente el amor entre hombres, mientras que Afrodita lo hace sobre el amor entre hombres y mujeres. En imágenes tardías, se lo representa como un niño travieso, muchas veces con los ojos vendados, equipado con un arco y flechas con las que atraviesa los corazones de los enamorados.

En este trabajo nos ocuparemos de rastrear -aunque sin pretensión de exhaustividad- las figuras de Afrodita y de Eros en los episodios míticos más conocidos 
o relevantes de la literatura clásica, en atención a dos líneas principales de interpretación de ambos dioses: las referidas al discurso amoroso y/o erótico que surge en torno a ellos y sus acciones y las vinculadas con el cuerpo y sus características.

\section{El amor y el discurso literario}

Hablar del amor es una "puesta a prueba del lenguaje" (Kristeva, 1999, p. 2) ya que implica dudar de su carácter unívoco y su poder referencial y comunicativo. Esta aseveración no resulta exagerada para el caso de los textos latinos ya que el sustantivo latino amor traduce tanto philia como erôs, y amare se emplea en todas las acepciones del verbo: 'hacer el amor', 'tener una amante', 'estar enamorado', 'tener amistad', 'amar $a^{\prime 1}$. Según explica Kristeva, el riesgo de un discurso amoroso radica, precisamente, en la incertidumbre de su objeto: ¿qué es el amor? y, más específicamente, ¿cómo se lo representa en los textos antiguos?

Para empezar a responder esta pregunta, podemos considerar las relaciones entre el amor y la literatura. Zimmermann (2003) explica que el erotismo en la literatura es la representación del amor en todas sus formas, teniendo en cuenta el componente sexual en una cuidadosa configuración literaria. En tal sentido, es necesario prestar especial atención tanto a los medios literarios y retóricos como a las estrategias por medio de las cuales cada autor intenta involucrar al lector o receptor eventual y ponerlo en relación con el texto erótico.

Los tópicos y modelos en la representación del erotismo se hallan en la literatura griega, en los textos homéricos. En el libro XIV de Ilíada, que narra la unión sexual de Zeus y Hera, los elementos y la forma en que está construido el pasaje marcarán los textos eróticos de la literatura griega hasta la época de los emperadores:

1) el acto sexual aparece en un solo verso; sin embargo, se concede gran importancia a todos los preparativos previos;

2) el lector 'participa' de la escena en tanto tiene expectativas, que el autor satisface o no;

\footnotetext{
${ }^{1}$ Según el Dictionnaire Étymologique de la Langue Latine, amor es un nombre de género animado, personificado y divinizado, con sentido abstracto y concreto (cf. Ernout y Meillet, 1959, p. 29).
} 


\section{Arqueología del amor: la representación de Afrodita y de Eros en el pensamiento antiguo.}

3) la ecfrasis (la descripción del cinturón de Afrodita en los vv. 214-221) se vuelve tradicional: "Dijo [Afrodita a Hera]; y desató del pecho el cinto bordado, de variada labor, que encerraba todos los encantos: hallábanse allí el amor, el deseo, las amorosas pláticas y el lenguaje seductor que hace perder el juicio a los más prudentes".

4) el amor se desencadena por medio del estímulo visual ${ }^{2}$;

5) la simpatía de la naturaleza por el deseo erótico que experimentan los héroes se transforma en un tópico;

6) la intriga y la astucia se unen para lograr el amor;

7) se establece el modelo de cómo Eros actúa sobre los hombres: la combinación de estímulos visuales y otros recursos sensuales, como el perfume y la vestimenta, junto a un discurso deslumbrante, provoca en el hombre un deseo de unión carnal que ofusca la razón.

En cuanto a Odisea, el libro VIII presenta los amores de Afrodita y Ares, que introduce el tópico del adulterio en su tono erótico y humorístico a la vez, locus classicus que tuvo notable influencia en la comedia y la elegía romanas ${ }^{3}$. Esta conocida historia aparece también a partir del verso 561 del Libro II del Arte de amar (Ars amandi) de Ovidio: "fabula narratur toto notissima caelo, Mulciberis capti Marsque Venusque dolis" (vv. 561-562: "se cuenta una historia famosísima en todo el cielo: Marte y Venus capturados en la trampa de Múlciber [Vulcano, esposo de Venus]" ${ }^{4}$ ). El memorable mito también es relatado por el autor latino en Metamorfosis (Met. IV 171-189) y, posteriormente, por Reposiano en su Concubitus Martis et Veneris (Anth. Lat. 253).

${ }^{2}$ El tópico del amor a primera vista, que alcanza a los hombres como un rayo, será sumamente importante en el desarrollo de la elegía y la novela (Zimmermann, 2003).

3 “No sólo el espectro de personajes (el marido feo, la esposa seductora y el atractivo y joven amante) marcó a la comedia, a la novela y a otros géneros como la elegía amorosa sino también la venganza urdida inteligentemente por el esposo cornudo contra la esposa y su amante" (Zimmermann, 2003, p. 159).

${ }^{4}$ Las traducciones del Arte de amar son de mi autoría. 
En el contexto que proponen Amores, el Arte de amar, los Cosméticos para el rostro femenino (De medicamine faciei femineae) y los Remedios del amor (Remedia amoris), el discurso amoroso se relaciona con la vida pública y el arte retórica: Roma es presentada en estas elegías como el símbolo del mundo y, en ese sentido, como el espacio más apropiado para los juegos del amor. Metamorfosis, por su parte, es un "compendio único de tradiciones míticas, en el que se conjuga la poesía con la mitografía" (Tola, 2005, p. 25). Ovidio sistematiza en esta obra el caudal de mitos que circulaba en la sociedad romana de su época y, por ello, constituye la fuente principal de los conocimientos actuales sobre la mitología grecolatina. Según Tola (2005), todas las clases de transformaciones que compendia la obra remiten a temáticas recurrentes en el texto, entre las que destaca: 1 ) la metamorfosis como resultado de la violencia ejercida sobre el cuerpo de la mujer por dioses o héroes; 2) la transformación como castigo por la jactancia o la transgresión de normas por parte de los mortales; y 3) la metamorfosis como resultado de pasiones prohibidas. En atención a ello, Metamorfosis resulta un espacio literario muy fecundo para estudiar la mitología en relación con el discurso amoroso y la representación corporal.

\section{Las cosas de Afrodita}

Como explica Foucault (2003), no existe entre los griegos una noción parecida a la de 'sexualidad' o a la de 'carne', que se refiera a una entidad única y que englobe fenómenos diversos y en apariencia alejados entre sí como comportamientos, sensaciones, imágenes, deseos, instintos y pasiones. Antes bien, los griegos disponían de una amplia gama de palabras para designar distintos gestos o actos que hoy se definen como 'sexuales', por ello la categoría de conjunto bajo la cual estos gestos, actos y prácticas se subsumían es difícil de captar. El adjetivo sustantivado ta aphrodisia, más o menos equivalente al término latino venerea, aludía a lo que podríamos llamar 'cosas' o 'placeres del amor', 'relaciones sexuales', 'actos de la carne' o 'voluptuosidades'. Sin embargo, prosigue Foucault, nuestra idea de sexualidad contempla una realidad de otro tipo, con otra moral y con otras funciones.

Las aphrodisia son 'las obras' o 'los actos de Afrodita' (ta erga Aphroditês): “Las aphrodisia son actos, gestos, contactos, que buscan cierta forma de placer" (Foucault, 


\section{Arqueología del amor: la representación de Afrodita y de Eros en el pensamiento antiguo.}

2003, p. 39). En síntesis, las aphrodisia eran todo aquello que mostraba el cinturón de la diosa.

¿Cuáles son la forma y la variedad de estos actos de Afrodita? Aristóteles se refiere a la cópula en el reino animal y la describe con detalle en el libro VI de la Historia de los animales. Sin embargo, los comportamientos sexuales humanos apenas son mencionados, lo cual no significa que la medicina, la filosofía o la moral griegas tuvieran una suerte de pudor, al modo cristiano, respecto de la actividad sexual. En realidad, cuando se interrogan sobre los actos placenteros, lo que los griegos se preguntan no es la forma que asumen sino la actividad que manifiestan: les interesa mucho más su dinámica que su morfología.

Esta dinámica queda definida por el movimiento que une a las aphrodisia, el placer que se les asocia y el deseo que suscitan. La atracción ejercida por el placer y la fuerza del deseo que lleva a él constituyen, con el acto mismo de las aphrodisia, una unidad sólida. (...), en la experiencia de las aphrodisia, acto, deseo y placer forman un conjunto cuyos elementos, desde luego, pueden distinguirse, pero están fuertemente ligados unos a otros (Foucault, 2003, pp. 41-42).

Sin duda, los aspectos que señala Foucault son los que se asocian a la figura de la diosa del amor y la belleza, que surgen de los episodios mitológicos que la tienen como protagonista, algunos de los cuales comentaremos a continuación.

\section{Matrimonios y algo más}

Hesíodo en la Teogonía (188-195) relata cómo los genitales de Urano, amputados por el acero de Cronos, fueron arrojados al mar y de ellos brotó la blanca espuma de la cual salió una joven. Cuando ella pisaba la tierra, la hierba crecía bajo sus pies encantadores. Era Afrodita, Ilamada así por haber nacido de la espuma, y conocida también como Citeres, porque primeramente fue llevada a ese lugar; como Ciprigenia porque luego arribó a Cipros (Chipre) y como Filomedea porque había salido de las partes genitales. Eros la acompañaba e Himero la seguía cuando se presentaba a la asamblea de los dioses; por elección de la moria, participaba entre los hombres y los 
dioses inmortales, en los encuentros de las vírgenes, las sonrisas, las seducciones, el dulce encanto, los cariños y las caricias (Alesso, 1999, pp. 13-14).

Afrodita debió tomar por esposo a Hefesto, pero cometió el adulterio más célebre de la Antigüedad, cantado en el libro VIII de Odisea (266-369), con el apuesto Ares. Según Alesso (1999), el tema principal de dicho episodio es un comportamiento sexual inadecuado $\left(\right.$ moixeia $\left.^{5}\right)$ que, empero, no sufre ningún castigo ejemplar. En realidad, quien aparece ridiculizado es Hefesto, por su insistencia en cobrar una compensación de su dote por la falta de su esposa. Afrodita, en cambio, resulta indemne, y más aún, ayudada por las Gracias, renueva su virginidad en el mar. Esto se explica porque, como sentencia Alesso (1999), la "divinidad femenina del solsticio de verano tiene un solo deber: hacer el amor" (p. 16).

El adulterio de Afrodita y Ares que narra Odisea será comentado, transmitido, parodiado e interpretado en los siglos posteriores con gran frecuencia. Uno de los intérpretes destacados del texto homérico fue Heráclito, el rhetor, gramático griego del siglo I que escribió un comentario alegórico sobre Homero y para quien la construcción textual de Afrodita se organiza "en torno de tres ejes mitográficos transmitidos por la tradición: a) infunde la pasión amorosa que obliga a Helena a abandonar a Menelao para huir con Paris, b) es herida por Diomedes por haber querido proteger a Eneas y c) es descubierta por su esposo Hefesto cuando comete adulterio con Ares" (Alesso, 2004, p. 153).

Respecto del primer eje, Afrodita simboliza la pasión en los arrebatos amorosos, ya que la diosa perturbó el ánimo de Helena, quien abandonó a su esposo Menelao por el amor de Paris, lo que desencadenó la guerra de Troya. El segundo eje supone para Heráclito la sinrazón, la irracionalidad de los combatientes bárbaros, ya que para proteger a Eneas (su hijo), que estaba a punto de morir a manos de Diomedes, la deidad cayó abrumada por el dolor en medio del tumulto. El tercer eje, los amores con Ares, encarna el desenfreno pero también la pacífica concordia para

\footnotetext{
${ }^{5}$ Alesso (1999) explica que moixeia se traduce habitualmente como 'adulterio', pero en realidad tiene un significado más amplio que engloba todo comportamiento sexual inapropiado, que puede ser castigado sin más por el kyrios, o sea por el tutor oficial legal de la mujer.
} 


\title{
Arqueología del amor: la representación de Afrodita y de Eros en el pensamiento antiguo.
}

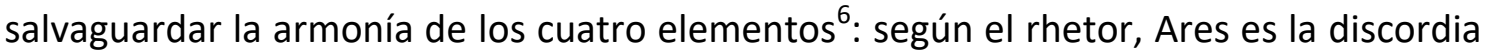
y Afrodita, la amistad, dos principios que, aunque separados en su origen, Homero presenta, después de su antigua rivalidad, unidos en íntima armonía.

Ovidio, también en el siglo I, recoge el episodio de Afrodita y Ares (Venus y Marte) en Metamorfosis, en los versos 167-189 del libro IV:

\author{
El primero que el adulterio de Venus con Marte vio \\ se cree este dios [el Sol]; ve este dios todas las cosas el primero. \\ Hondo se dolió del hecho y al marido, descendencia de Juno, \\ los hurtos de su lecho y del hurto el lugar mostró; mas a aquél, \\ su razón y la obra que su fabril diestra sostenía, 175 \\ se le cayeron: al punto gráciles de bronce unas cadenas, \\ y redes y lazos que las luces burlar pudieran \\ lima -no aquella obra vencerían las más tenues \\ hebras, no la que cuelga de la más alta viga telaraña- \\ y que a los ligeros tactos pequeños movimientos obedezcan 180 \\ consigue, y el lecho circundando las coloca con arte. \\ Cuando llegaron a este lecho, al mismo, su esposa y el adúltero, \\ con el arte del marido y las ataduras preparadas de novedosa manera, \\ en mitad de sus abrazos ambos sorprendidos quedan. \\ El Lemnio [Vulcano] al punto sus puertas marfileñas abrió 185 \\ y admitió a los dioses; ellos yacían enlazados \\ indecentemente, $\mathrm{y}$ algunos de entre los dioses no tristes desea \\ así hacerse indecente... Los altísimos rieron y largo tiempo \\ ésta fue conocidísima hablilla en todo el cielo. ${ }^{7}$
}

\footnotetext{
${ }^{6}$ Para el neoplatonismo en general (Salustio y Filón de Alejandría, entre otros), Afrodita, junto con Apolo y Hermes, son los dioses que armonizan el mundo.

${ }^{7}$ Ovidio también narró el adulterio de Marte y Venus en el Arte de amar, como ya hemos mencionado, episodio que le permite aconsejar al marido cómo proceder ante la infidelidad de su esposa. En dicha lección, Vulcano (Hefesto) representa el exemplum a contrario, es decir la forma en la que no se debe actuar y que la propia Venus, que apoya al poeta (Ars 2.15), prohíbe (Ars 2.593-4).
} 
Como en muchos otros mitos de Metamorfosis, el de Venus y Marte es presentado desde la perspectiva de alguien 'que ve': en este caso la mirada del dios Sol, que alertó a Vulcano del engaño, y la del resto de los dioses, testigos del resultado de la trampa tendida por el cornudo esposo a los amantes. El tema de lo prohibido, abordado en varios de los mitos compendiados por Ovidio, no recibe un tratamiento profundo en este pasaje dado que, como dijimos antes, pese al sentido básico del adulterio como transgresión de normas, no se advierte un castigo (una metamorfosis) para la infiel Venus, a menos que consideremos en tal sentido la vergüenza de quedar atada y desnuda frente a los dioses.

Según Llanos (2011), la ausencia de lección moral relacionada con el relato del adulterio de los dioses, tanto en Odisea como en Metamorfosis, puede explicarse por la gran extensión en versos que ocupa en el pasaje la descripción de la trampa, vinculada metafóricamente con la telaraña, que supone un énfasis de los autores en la acción de relatar historias ('tejer' textos, valga la redundancia) como fuente de placer.

Sin embargo, podemos incluir el episodio de Venus y Marte de Metamorfosis entre las narraciones marcadas por la idea de lo prohibido. Como explica Tola (2005), en primer lugar lo prohibido se relaciona con lo erótico en tanto sus protagonistas vulneran reglas de ese ámbito. En segundo término, lo ilícito puede vincularse con la transgresión de ciertas normas sociales como, en el caso que nos ocupa, las del matrimonio. "Este tipo de narraciones pone en evidencia, bajo diversas formas, el problema de la identidad y de sus conflictos $y$, de un modo general, otro de los conceptos clave de la cultura romana, el furor" (Tola, 2005, p. 61). Desde la perspectiva filosófica, el término furor designaba pasiones violentas como la ira y el amor desmedido, cuyos casos extremos eran el adulterio, el incesto y los atentados al pudor. Para los poetas elegíacos, como lo fue Ovidio, este sentimiento era el elemento clave de la experiencia amorosa que trataban en sus obras.

En todos los casos, el furor alude entonces a situaciones límite que implican la falta de control de quienes lo padecen. En el ámbito de lo erótico, que tanto fascinó a Ovidio a lo largo de su carrera literaria, este sentimiento refiere, por un lado, en Metamorfosis, a una transgresión de las normas que pone en juego las nociones de identidad y 


\section{Arqueología del amor: la representación de Afrodita y de Eros en el pensamiento antiguo.}

alteridad, y, por otro, a casos en los que ese comportamiento tergiversa monstruosamente ciertas normas sociales. El dominio de Eros es percibido así, (...), como el de la puesta en peligro del ser, el de la transgresión y el del riesgo de muerte (Tola, 2005, p. 61).

Asimismo, el término furor, en el terreno del derecho, se aplicaba a quienes por su comportamiento insensato requerían la presencia de alguien que actuara en su nombre. Ese sentido aparece parodiado en el Arte de amar cuando el poeta menciona, entre todos los lugares propicios para el amor, el foro: "et fora conveniunt (quis credere possit?) amori / flammaque in arguto saepe reperta foro" ("y los foros convienen para el amor (¿quién podría creerlo?) / y la llama muchas veces fue encontrada en el ruidoso foro", Ars 1.79-80). En aquel lugar, el letrado muchas veces es atrapado por el Amor ("Illo saepe loco capitur consultus Amori", Ars 1.83). La idea del amor que surge del verso 83 se completa con la de los versos siguientes (84 a 89) en los que se muestra al abogado indefenso y sin el recurso de las palabras adecuadas: cautivo del amor, ahora es él quien necesita alguien que se ocupe de su causa. La posesión de un espacio vital propio -como, en este caso, el de la profesión- se presenta como equivalente de la vida misma y dicha equivalencia instaura la idea de identidad. En el ejemplo concreto de los versos ovidianos, al ser capturado por el amor, el abogado se sale de su espacio propio, se enajena ya que se transforma en un ser desprotegido porque ha perdido su ubicación en el locus de la propia identidad.

Como vemos, la idea de furor que es posible adjudicar a Afrodita en Metamorfosis se acerca mucho a los sentidos alegóricos que Heráclito, el rhetor, atribuía a la diosa en su análisis de la obra homérica. Asimismo, ese furor que la caracteriza alcanza también a los cautivos del amor, sentimiento que alegoriza Ovidio en su elegía más conocida.

El foro era para Ovidio un lugar ideal para el amor, aunque no el único ${ }^{8}$. Tal como describen los versos del Arte de amar, en el foro de Roma estaba el monumento

\footnotetext{
${ }^{8}$ En efecto, otro de los espacios urbanos recomendados por el poeta en el Arte de amar para encontrar mujeres bien dispuestas a una relación amorosa eran los teatros (Miranda, 2003).
} 
de Venus, un templo hecho de mármol (Veneris facto de marmore templo, Ars 1. 81) ${ }^{9}$. El verso siguiente (Hunc Venus e templis, quae sunt confinia, ridet,) presenta a Venus en lo alto de su templo, desde donde se ríe de los seres atrapados por el sentimiento amoroso. La risa de Venus define, sin duda, la concepción festiva del amor y de la elegía ovidiana respecto de la indefensión de los hombres frente a la fuerza arrolladora del amor.

Pero no solo con Ares tuvo amores la diosa Afrodita. Entre los romanos, Venus era especialmente venerada por haber dado a luz a Eneas, luego de su relación con el mortal Anquises. Es decir que la deidad se inscribe en la mitografía romana en relación con los orígenes de la civitas, más que como personaje de una epopeya protohistórica. La versión que vincula a Afrodita con la progenie latina proviene, en lengua griega, del Himno homérico a Afrodita (45-200), que relata que la diosa durmió con un mortal y ambos fueron los padres de Eneas. Afrodita se enamoró de Anquises, rey de los Dardanios, cuando lo vio en el monte Ida, y para inducirlo a amarla, le aseguró que ella también era mortal, hija del rey de Frigia. La Eneida de Virgilio es la obra más importante de la tradición clásica que presenta a Afrodita como la madre de Eneas, cuyo descendiente Rómulo fundará Roma, centro de la gran civilización que dominará el mundo mediterráneo de la Antigüedad, aunque el mito también aparece en los textos de historiadores destacados como Plutarco (Vidas paralelas) y Tito Livio (Ab urbe condita libri).

Sin embargo, como explica Galán (2005), la divinidad virgiliana está más próxima a la Afrodita Urania o celeste (relacionada con las fuerzas vitales de la naturaleza) que a la Afrodita Pándemos o terrena de los griegos (la que gobierna junto con su divino hijo Eros los asuntos amatorios).

La figura de Venus tiene una elevada e insoslayable significación para los romanos y desde sus orígenes aparece como una divinidad netamente propiciatoria. De allí que dos palabras de evidente filiación venusina, venerari ("venerar", el llamado a la

\footnotetext{
${ }^{9}$ Se refiere, seguramente, al templo de la Venus Felix (Venus que trae la buena fortuna), que exalta el valor de la protección divina.
} 


\section{Arqueología del amor: la representación de Afrodita y de Eros en el pensamiento antiguo.}

divinidad) y venia ("la aceptación o anuencia", la respuesta que recibe el orante), representan los dos movimientos complementarios de la actitud religiosa. (...) [Se interpreta el nombre de la divinidad] como la personificación de una cualidad básicamente ligada a la mujer: el encanto, en su sentido mágico-religioso. En sucesivas etapas, pues, la Venus itálica entra en conjunción con la Afrodita griega y se une a la leyenda troyana. Su virtud propiciatoria se convierte en certeza doctrinal para los romanos (Galán, 2005, p. 103).

En forma paulatina, Venus ingresa en la vida cívico-militar de la República romana y se convierte en la diosa de la Victoria, en honor de quien se erigen templos y altares para celebrar sus virtudes de tipo militar. En principio, Venus es reivindicada por el pueblo romano, luego por las familias (gentes) en nombre de sus pretensiones genealógicas y finalmente por un solo hombre, que se proclama su favorito y privilegiado protegido (Pompeyo), práctica que tendrá vigencia hasta la época de Augusto. No se trata ya, como es posible advertir, solo de una diosa amatoria sino de un principio cósmico, generador de vida y grandeza y una activa potencia material y política (Galán, 2005).

La Venus de la Eneida es presentada por Virgilio en la máxima extensión de sus potestades, como defensora del pueblo romano, de la familia de Anquises y de su hijo Eneas. La protección a Eneas significa, ni más ni menos, el favor hacia la gens que se convertirá en el pueblo rector del mundo. No desaparecen en esta representación de la diosa, sin embargo, sus poderes eróticos, ya que estos están al servicio de la operación fundacional, como demuestra el tema del trágico amor de Dido, reina de Cartago, hacia el troyano Eneas, por obra de Cupido, que aparece en el Libro I y que abarca todo el IV de la magna obra épica virgiliana.

Pero volvamos a los mitos griegos. Entre ellos, es recordado el mito de que Afrodita y Dionisos fueron los padres de Príapo, el feo niño de enormes genitales. Además, luego de pasar una noche con Hermes, Afrodita engendró a Hermafroditos, 
un ser de doble sexo. También entregó noches de amor a Poseidón, con quien tuvo dos hijos: Rodos y Herófilo ${ }^{10}$.

Los famosos y bellos amores de Afrodita y Adonis, narrados por el Pseudo Apolodoro (siglo I o II d. C.), suelen explicarse como un mito de la vegetación en el que el dios muere cada año y vuelve a la vida en la época de las cosechas. Afrodita se enamora del joven y con él pasa las dos terceras partes del año, hasta que Adonis resulta herido por un jabalí y muere. El Imperio romano fue particularmente proclive a este relato en el que Afrodita se enamora del apuesto Adonis, que Ovidio narra en Met. X (502-558):

Cautivada de tal hombre por la hermosura, ya no cura de las playas de Citera, no, de su profundo mar ceñida, vuelve a Pafos, y a la rica en peces Gnido, o a Amatunta, grávida de metales. 530 Se abstiene también del cielo: al cielo antepone a Adonis.

Otro mito muy difundido que tiene a Afrodita como una de sus protagonistas es el del juicio de Paris. Si bien hemos afirmado antes que Afrodita era una de las deidades que armonizaban el mundo, su presencia no se halla enteramente alejada del conflicto y la contrariedad. En tal sentido, conocido es el juicio de Paris, es decir el mito de la manzana de la discordia, objeto destinado por la diosa Eris (la Discordia) a 'la más bella' de las diosas invitadas a las bodas de Peleo y Tetis. Hera, Atenea y Afrodita reclamaron la manzana y pusieron como árbitro a Zeus, quien delegó la decisión en el joven y hermoso Paris. Hera le prometió a Paris poder y riquezas si la escogía a ella; Atenea le aseguró gloria en las guerras y gran fama; y Afrodita, por su parte, le ofreció la mujer más hermosa por esposa. Paris eligió a la diosa del amor: ella obtuvo la manzana de oro y él consiguió el amor de Helena, lo que dio origen a la guerra de Troya, y atrajo sobre sí la ira de las dos diosas que se sintieron despreciadas. Como ocurre con muchos relatos mitológicos, los detalles del juicio de Paris varían de una

\footnotetext{
${ }^{10}$ Todos estos mitos son recogidos por Diodoro Sículo en Bibliotheca historica, escrita entre el año 60 y el 30 a. C. (cf. Alesso, 1999, p. 22).
} 


\section{Arqueología del amor: la representación de Afrodita y de Eros en el pensamiento antiguo.}

fuente a otra. La historia es aludida por Homero en el libro XXIV de la Ilíada. Más detalles incluyen Ovidio en las Heroidas, Luciano en los Diálogos de los dioses e Higino en las Fábulas; Eurípides lo menciona también en algunas de sus tragedias.

\section{Amor, deseo y erotismo}

Según Kristeva (1999), existe una historia de las actitudes y de los discursos amorosos que conforma los sedimentos del eros occidental. La primera capa de este depósito se encuentra en El banquete (385 a. C.) y en Fedro (386 a. C.) de Platón, obras en el que se manifiesta bajo los rasgos del amor homosexual ${ }^{11}$. Esta erótica se invierte, sin embargo, en el seno mismo de la obra platónica, como una elevación hacia el Bien supremo a través de la visión de lo Bello. "Eros -posesión devastadora- se convertirá en el siglo VI antes de Cristo en un Pteros, pájaro idealizado cogido en el movimiento ascendente del alma, ciertamente caída, pero que se acuerda indefectiblemente de haber estado más arriba" (Kristeva, 1999, p. 51). También Rougemont (1997) entiende al amor presentado en Fedro y en El banquete como un frenesí que va desde el cuerpo al alma. Se trata de un "furor" o "delirio que no se engendra sin alguna divinidad ni se crea en el alma dentro de nosotros: es una inspiración extraña del todo, un atractivo que actúa desde afuera, un arrebato, un rapto indefinido de la razón y del sentido natural" (Rougemont, 1997, p. 61). A dicho furor se denomina, precisamente, 'entusiasmo', que significa 'endiosamiento', pues ese delirio proviene de la divinidad y conduce el impulso humano hacia Dios.

El amor platónico es, entonces, un 'delirio divino', la vía por la que el éxtasis asciende por grados hacia el origen único de todo lo existente. El eros es, en pocas palabras, el deseo total, la aspiración luminosa, el impulso religioso natural llevado a su más alta potencia, a la extrema exigencia de pureza. Pero dicha fuerza suprema del deseo desemboca en lo que no es deseado:

\footnotetext{
11 Es menester entender lo homosexual más allá del amor por los paidoi y concebirlo como una identificación de los sexos, bajo la protección de un ideal instituido.
} 
La dialéctica del Eros introduce en la vida algo totalmente extraño a los ritmos del atractivo sexual: un deseo que no decae, que nada puede satisfacer, que rechaza incluso y huye de la tentación de colmarse en nuestro mundo, porque no quiere abrazar sino el Todo. Es (...) la ascensión del hombre hacia su dios. (...) Eros quiere la unión, es decir, la fusión esencial del individuo en el dios (Rougemont, 1997, pp. 62 y 72).

Posteriormente, a través de la reflexión neoplatónica, y apoyada por el mito de Narciso, esta erótica ascendente se interioriza y crea el espacio interior como reflexión de un alter-ego, de un yo idealizado. Este cambio legará una nueva concepción del amor a Occidente: el amor centrado en sí mismo, aunque atraído hacia el otro ideal (Kristeva, 1999).

Por otra parte, la corriente bíblica se unirá a estos elementos griegos para modelar la materia de los amores occidentales. El judaísmo impone el amor heterosexual, cuya ética se sustenta en la familia y en la reproducción. El amor por el otro y, hablando más claramente, el amor por el otro sexo, llegará por primera vez a nuestra cultura de la mano del rey Salomón y de la Sulamita, a través de los versos gozosos del Cantar de los Cantares, símbolo del placer y el erotismo en el marco del amor conyugal.

El cristianismo desarrollará, desde los Evangelios, la concepción ya no de Eros, sino de Ágape, el amor divino de Dios. Si bien Ágape asume "la erótica griega disfrazada en los dramas de la pasión propia de la carne" (Kristeva, 1999, p. 52), agrega también la discreción del ardor familiar y la tensión de un inquebrantable amor a Dios y a los otros. Frente a este amor del Padre que es Ágape, a partir de Bernardo de Claraval, en el siglo XII, se impondrá el amor materno y la imagen de la Virgen María con el Niño Jesús devendrá, para todo Occidente, en el puntal de los aspectos más preciosos, tranquilizadores y protectores del amor.

De estos componentes se forjarán los mitos amorosos más persistentes en nuestra cultura: Tristán e Isolda, la pareja prohibida, imagen del amor-muerte y de los apetitos enfrentados a la ley; Don Juan, el seductor incrédulo dominado por la pasión 


\section{Arqueología del amor: la representación de Afrodita y de Eros en el pensamiento antiguo.}

de someter pero sin poseer al otro; Romeo y Julieta, los hijos malditos de Verona, que conjuran al odio que, finalmente, consumirá su pura pasión.

Mezcla exquisita de posesión destructora y de idealización, cresta entre el deseo que es un flujo y la prohibición que pone fronteras, el amor sólo cruza el umbral de la Edad Moderna en la literatura. Cuando la teología se retira ante una filosofía que basa el ser en el conocimiento más que en el afecto, es la retórica -como en los momentos de la eclosión amorosa- la que recoge la pasión y el entusiasmo de los enamorados. Pero después del desencantamiento sádico de la pulsión, así como después del voyeurismo más o menos inspirado de la pornografía, ¿encuentra el amor contemporáneo la dosis deliciosa de irritación y elevación, de fulgor y paz, para mantenerse? Y en caso afirmativo, ¿cuál es esa nueva dosis? (Kristeva, 1999, pp. 5354).

No ofrece la filósofa búlgaro-francesa una respuesta a sus propios interrogantes sobre el amor en la cultura contemporánea, pero afirma -y coincidimos con ella- que los viejos mitos perviven entre nosotros y es necesario remontarse a Grecia para encontrar sus raíces y prolongaciones.

\section{El alma y el deseo}

Una de las primeras elaboraciones de la noción de deseo se debe a la figura de Sócrates, quien en El banquete, a instancias de una polémica que sostiene con Agatón (200b y ss.), lo muestra como una inclinación que busca compensar lo que al sujeto le falta: el deseo solo puede tomar por objeto aquello de lo cual el sujeto carece, por eso desear lo que ya se tiene no es otra cosa que la continuidad y permanencia de lo que ya se posee para seguir gozándolo. Sócrates demuestra, a partir de este principio, que Eros, pese a que hace gala de la belleza y el amor como símbolos de su divina autoridad, carece de ellos: la prueba reside, precisamente, en el hecho mismo de que los desea (Naughton, 2005).

En los dos grandes diálogos platónicos consagrados a Eros, El banquete y Fedro, 
Amor significa siempre e indistintamente amor a los jóvenes, amor al Bien y amor al discurso verdadero. Pederasta y filósofo a la vez, Eros puede, consecuentemente, acariciar otros cuerpos (la hipótesis de que concierne también a la mujeres es evocada por Pausanias o Aristófanes, por ejemplo). Pero, formulado en el seno del discurso filosófico que se está constituyendo como tal, llevado, pues, por un filósofo en busca de su ser, Eros es esencialmente el deseo de lo que le falta a este hombre. Después de hacerle comprender que el amor es siempre amor a algo (El banquete, 199d), Sócrates precisa que en el amor, como en el deseo, el objeto es, para el que lo siente, "lo que no tiene a su disposición y no está presente, lo que no posee, algo que él no es y aquello de que carece" (Kristeva, 1999, pp. 53-54).

La idea de deseo como privación recorrerá casi toda la Antigüedad clásica, como lo demuestran las sentencias de Séneca, Ovidio, Horacio, Quintiliano y otros pensadores. Para Foucault, esta persistencia de la concepción del deseo vinculado a la carencia conforma la "estructura discursiva" de una episteme (Albano, 2004) ${ }^{12}$. Según Naughton, la dimensión de carencia fenoménica asociada a la noción de deseo supone una correspondencia y adecuación de los objetos que le son propios, lo que da lugar a una tipología de deseos conforme a ciertos objetos apetecibles y deseables que le resultan adecuados. En el mundo antiguo, "se trataba de 'desear lo adecuado', evitando con ello toda clase de desproporciones y excesos" (Naughton, 2005, p. 26).

Ello explica, en gran medida, que durante la Antigüedad clásica, el deseo y la exaltación erótica no fueran objeto de represión; por el contrario, se recomendaban como ejercicio y formaban parte de los 'bienes corporales' a los que el ciudadano podía y debía aspirar con todo derecho. En Grecia se aconsejaba a los ciudadanos adultos que adoptaran a un mancebo bajo su cuidado y tutela, al que se lo llamaba

\footnotetext{
${ }^{12}$ Una estructura discursiva es una suerte de sustento conceptual que permite establecer lazos de coherencia y de sentido entre las distintas manifestaciones intelectuales, económicas, artísticas y políticas de una determinada época a partir de semejanzas y equivalencias de superficie (Albano, 2004).
} 


\section{Arqueología del amor: la representación de Afrodita y de Eros en el pensamiento antiguo.}

erastês ('amante'), y el comercio sexual entre protector y adoptado era un componente necesario y constitutivo de dicho vínculo ${ }^{13}$.

Como aspiración a la unión con el Bien supremo y a la inmortalidad, este deseo de lo que falta y que utiliza el cuerpo del joven para compensarlo es considerado por Platón como un intermediario. Un daimôn o mensajero que está llamado a llenar un vacío para constituir una unidad total, una "apoteosis del alma conducida de esta manera por Eros lo más cerca posible de su unificación de lo divino" (Kristeva, 1999, p. 54), viaje iniciático que, en el Fedro, constituye el espacio daimónico (intermediario, interpretativo y sintético) de la Psique.

Por Eros, según el Fedro, así como por la filosofía, el alma caída, que ha perdido sus plumas, se volverá a adornar con ellas y ascenderá hacia las alturas celestes, e incluso supracelestes, que son las que motivan su movilidad, su acción y, más concretamente, su amor. El Fedro demuestra cómo Psique y Eros son interdependientes, al convertirse el alma en el espacio necesario, el receptáculo de la pasión amorosa. Muchos son los que se han preguntado si había necesidad de mezclar en un mismo diálogo consideraciones sobre el amor y sobre el alma. Sin embargo, basta con poner de manifiesto la complicidad entre las dinámicas que constituyen ambas entidades, Eros y Psique, para comprender que, no sólo en mitología sino también en la misma base del discurso filosófico, amor y alma son indisociables. (Kristeva, 1999, pp. 54-55)

Esta dinámica común al alma y al amor tiene, según explica Kristeva, una representación fálica. Sócrates lo manifiesta casi explícitamente al comparar la ascensión del alma enamorada con el vuelo de un pájaro: Psique-Eros-Pteros. La descripción de cómo actúa el alma enamorada, o tal vez el amor mismo -dado que

\footnotetext{
${ }^{13}$ Por la misma razón, la práctica homosexual se hallaba muy distante de ser objeto de censura, excepto en los casos de excesos voluptuosos o conductas desenfrenadas relacionadas con la locura amatoria -en tanto expresaban una desproporción con respecto a la sofrosyne, es decir, el 'justo medio' en el cual debía permanecer el hombre virtuoso-. Así, el desborde amatorio de Alcibíades con respecto a Sócrates relatado en El banquete es reprobado por su intemperancia y no por la razón del objeto homosexual.
} 
para la filosofía el amor es cosa del alma- ${ }^{14}$, aunque supone la idealización y el movimiento pedagógico que tiene toda metáfora, impone una imagen sexual claramente masculina al hablar de una 'erección' de dientes o de plumas, de una 'inflamación', de un 'hinchamiento' o una 'ebullición'. Acordamos con Kristeva (1999) en que el alma así interpretada, en su connotación sexual más evidente, hace explicables las dudas que tuvieron los Padres de la Iglesia para concebir que las mujeres también tenían alma.

\section{Las travesuras de Eros}

Como apuntábamos al inicio, Eros remite en Grecia a representaciones muy diversas según las épocas. Para Hesíodo, Eros nace del Caos y preside las uniones de los titanes, concebidos por Gea (la Tierra); luego, las de los olímpicos y, finalmente, las de los hombres. Así, Eros es el principio cosmogónico que favorece y asegura la generación y reproducción de las especies. De este dios cuentan los poetas griegos que "era el más bello de los dioses, y que subyugaba el alma y la voluntad de todos los dioses y los hombres" (Teogonía, 120 y 122).

En la teología órfica, que tuvo gran difusión e influencia en la antigua Grecia, Eros surgió con sus alas de oro del huevo primordial, emblema de la venturosa plenitud que, al dividirse, formaría el Cielo y la Tierra. Es un ser doble, bisexual, capaz de unificar con su poder los aspectos desemejantes, incluso opuestos, de un mundo concebido como una fragmentación y degradación del Ser inicial.

\footnotetext{
14 “Pues se calienta al recibir por medio de los ojos la emanación de la belleza con la que se reanima la germinación del plumaje. Y una vez calentado, se derriten los bordes de los brotes de las plumas que, cerrados hasta entonces por efecto de su endurecimiento, impedían que aquéllos crecieran. Más al derramarse sobre ellos su aliento la caña del ala se hincha y se pone a crecer desde su raíz por debajo de todo el contorno del alma; pues toda ella era antaño alada. $Y$ en este proceso bulle y borbota en su totalidad, y estos síntomas que muestran los que están echando los dientes cuando éstos están a punto de salir, ese prurito y esa irritación en torno a las encías, los ofrece exactamente iguales el alma de quien está empezando a echar las alas. Bulle, está inquieta y siente cosquilleos en el momento en que le salen las plumas" (Fedro, 251b).
} 


\section{Arqueología del amor: la representación de Afrodita y de Eros en el pensamiento antiguo.}

En otras versiones, el mítico personaje era hijo de Afrodita y se contaba entre los dioses menores como Pan, Príapo, Proteo, Caronte, Himeneo, Tritón, Cibeles, entre otros. Este Eros es el equivalente al latino Cupido o Amor, cuyo padre era una veces Hermes, otras Hefestos o, incluso, el famoso amante de la diosa, Ares. Esta genealogía, además de señalar a sus padres, también lo presenta como hermano de Anteros (el amor correspondido). Esta figura de Eros es la más popular, muy difundida iconográficamente, y de la que se cuentan toda suerte de aventuras y picardías (Martín, 2005).

Según Ovidio en el libro IV de Fastos, los amores son tres: Eros, 'el amor', hijo de Venus y Mercurio (Hermes); Anteros, 'el amor recíproco', hijo de Venus y Marte (Ares); y Desiré, 'el deseo' hija de Venus y $\operatorname{Pan}^{15}$.

El arte y la literatura clásica representan a este Eros como un hermoso adolescente, protector de los amores homosexuales, pero también como un niño travieso munido de un arco, para disparar sus flechas contra los dioses y los hombres, o de una antorcha, para inflamar los corazones de una pasión irreprimible.

Entre los poetas romanos, Eros, bajo el nombre de Cupido, es una figura omnipresente. Virgilio muestra en la Eneida cómo Venus recurrió a él para provocar el amor de Dido hacia Eneas. Venus teme que Eneas se enamore de Dido, la reina de Cartago, lo cual constituiría una grave amenaza para la empresa de la fundación de Roma que llevan adelante los troyanos, con Eneas a la cabeza. Por ello, la diosa recurre al poder de su hijo Cupido para desviar hacia Dido el furor pasional que, en caso de ser aprovechado por Juno (diosa protectora de los africanos), podría retener a Eneas en Cartago. Entonces, Ascanio o lulo, el hijo de Eneas, es raptado momentáneamente por Venus y Cupido toma su aspecto para seducir a la reina gracias a su parecido con el héroe. "Es muy interesante la psicología de Venus: esta sobredosis divina de amor

\footnotetext{
${ }^{15}$ La diferenciación entre los tres amores aparece en Fastos en la explicación del mes de abril, dedicado a la diosa Afrodita (Venus). Este mes recibe el nombre de Aprilis, que significa 'espuma' (áphros), porque de la espuma fue procreada Venus, la diosa del amor. También se relaciona con el verbo latino aperire (abrir) porque la primavera, tan ligada a Venus, todo lo abre.
} 
arrebatado protegerá a su hijo y le evitará el extravío de desear lo que no puede poseer" (Galán, 2005, p. 29).

La figura de Amor/Cupido en la obra elegíaca de Ovidio también es relevante. Muchas veces se construye en relación con los tópicos literarios que el autor utiliza y que ponen de manifiesto su familiaridad con la práctica literaria.

Uno de los tópicos más recurrentes en las obras amatorias del poeta es el de la milicia del amor o militia amoris, desarrollado de manera monográfica en Amores 1,9 [Todo amante es soldado], y que consiste en la transferencia de conceptos y términos propios de la contienda bélica al vínculo amoroso. Veamos algunos ejemplos: "Militat omnis amans, et habet sua castra Cupido" ("Todo amante es soldado y Cupido tiene su propio campamento", Amores, I, 9, 1); (165) "Illa saepe puer Veneris pugnavit harena" ("Muchas veces en esa arena luchó el hijo de Venus", Ars, I, 165); "Militiae species amor est; discedite, segnes: / non sunt haec timidis signa tuenda viris. / Nox et hiems longaeque viae saevique dolores / mollibus his castris et labor omnis inest" ("El amor es una especie de milicia, iapártense de él los apáticos!: estas consignas no deben ser defendidas por hombres tímidos. Noche, invierno, largas vías y dolores crueles y toda clase de fatigas se hallan en este delicado campamento", Ars, II, 233-236) ${ }^{16}$.

En relación con este tópico se encuentra el del servitium amoris o esclavitud del amor, que resulta fundamental en los textos ovidianos puesto que define la relación de servidumbre del amante con respecto a su amada o domina ${ }^{17}$. Este tema ha dejado un legado de gran importancia para la cultura occidental en lo que se refiere a los roles de

\footnotetext{
16 “La noción del amor, que envuelve a la que tenemos de la mujer, se encuentra pues vinculada a una noción de sufrimiento fecundo que halaga o legitima oscuramente, en lo más secreto de la conciencia occidental, el gusto por la guerra. Ese círculo singular de cierta idea de la mujer y de una idea correspondiente de la guerra, en Occidente, implica profundas consecuencias para la moral, la educación y la política" (Rougemont, 1997, p. 247).

${ }^{17}$ Al amor y al sometimiento también se refiere el Fedro. Fedro expone la concepción del retórico Lisias, que es rechazada por Platón. La dialéctica del amo y del esclavo parece estar en la base de la relación amante-amado (erastês-eromenos), idea corregida, y hasta transformada, por la intervención de un delirio 'recto', guiado por la prudencia, ya que el amado, sometido al alma ardiente del amante, concibe el anteros, una especie de contra-amor cuyo apacible consentimiento equivale a una amistad filial.
} 


\section{Arqueología del amor: la representación de Afrodita y de Eros en el pensamiento antiguo.}

los amantes, que pervivió en el concepto medieval del amor cortés, posteriormente en el petrarquismo y, a través de él, en gran parte de la representación literaria del amor en Occidente ${ }^{18}$

A estos tópicos podemos sumar otras formulaciones también codificadas previamente y relacionadas con el tema del amor, como es el caso del locus amoenus, que consiste, básicamente, en la descripción idealizada de la naturaleza, con elementos naturales que se repiten (prado, sombra, aves canoras, arroyo cristalino) y que tiene como objetivo la creación de un ambiente perfecto:

la palabra amoenus, 'ameno, agradable, placentero'; es el adjetivo que Virgilio aplica constantemente a la naturaleza "hermosa" (cf. Eneida, V, 734, y VII, 30). En su comentario, Servio deriva la palabra de amor ${ }^{19}$. Son "Iugares amenos" los que sólo sirven para el placer, los que no están destinados a fines utilitarios (loca solius voluptatis plena..., unde nullus fructus exsoluitur $)^{20}$. El locus amoenus aparece como término técnico en el libro XIV de la enciclopedia de San Isidoro. (...) en esta enumeración aparecen también los loca amoena, con el mismo sentido que les daba Servio. Así, pues, en San Isidoro el locus amoenus es un concepto de la configuración geológica; por otra parte, ya desde Horacio (Ars poetica, 17) el término había servido para las descripciones retóricas, y en ese sentido lo habían interpretado los comentadores de Virgilio. (Curtius, 1975, p. 276)

El amor es una noción rica y diversa en la obra amatoria de Ovidio, que incluye todo tipo de personas y de relaciones. Por todo ello, la representación discursiva del amor en los poemas elegíacos implica varios aspectos. Por un lado, la aprehensión del concepto abstracto que significa el sentimiento amoroso se concreta a través de las

\footnotetext{
${ }^{18}$ Para un análisis minucioso del tópico medieval del amor cortés y su influencia en el mundo occidental remito a Rougemont (1997), Ciorda y Funes (2012) y Miranda (2015).

19 Sin embargo, esta derivación es oscura (cf. Ernout et Meillet, 1959, p. 29).

${ }^{20}$ Este fragmento que incluye Curtius en su texto corresponde a Marco Onorato Servio, estudioso y gramático de fines del siglo IV d.C., quien realiza un comentario de la Eneida (VI, 638) a propósito del locus amoenus: lo considera un lugar de delicia natural que permite confortar y recrear el espíritu.
} 
metáforas que lo convierten en una entidad sensible: el cuerpo y sus partes, el hombre y la mujer, la actividad sexual y otros comportamientos, el fuego, entre otros. Por otra parte, si bien las personificaciones alegóricas de Amor, Cupido y Venus alejan la representación del ámbito concreto, las acciones humanas que ellos llevan a cabo, como luchar, cautivar, reír e incitar (propias de la actividad cotidiana, particularmente corporal), intensifican su connotación metafórica ontológica. Por último, el uso de las metáforas orientacionales, principalmente, provee dos connotaciones a la designación del amor: una positiva y una negativa. La polaridad bueno/malo puede evidenciarse en las dos denominaciones que el amor recibe en el Arte de amar-Amor y Cupido (acompañado por Venus)- y en las direcciones ascendente/descendente que tienen los movimientos representados por las metáforas. El resultado general es el amor presentado como un combate $y$, por ello, muchas veces el miles (el soldado, metafóricamente el galán) resulta herido y dañado: Saucius ingemuit telumque volatile sensit, ("y [el espectador de los teatros] malherido gime y siente la flecha volátil [el dardo de Cupido]", Ars, I, 169). El dolor del amor, que se siente en el cuerpo, completa su matiz negativo a través del sentido que provee la idea del dardo de Cupido que vuela e impacta en el enamorado.

El nacimiento de Eros gracias a la unión de Poro y Penía es el que elige Platón en El banquete. Según este mito, Penía (la Pobreza, la Carencia), no invitada al banquete de los dioses, aguarda las sobras de la comida en la puerta del jardín y se une a Poro (el Recurso) que, aturdido por la embriaguez, se había quedado dormido. Penía es fundamentalmente una privación de forma, una materia bruta, que simboliza la ausencia de toda determinación, no iluminada por los dioses, rechazada por ellos, que aspira inútilmente a su familiaridad. Contrariamente, Poro es hijo de la Prudencia, de Metis, "proi de las rutas, de las delimitaciones de los espacios celestes o marítimos, de lo que ilumina la oscuridad de las aguas primordiales y abre camino al sol" (Kristeva, 1999, p. 62). Tramposo y astuto, Poro está ligado a la techné; es aquel que sabe encontrar los medios para conseguir sus objetivos. Estos dos padres opuestos y complementarios, Poro y Penía, engendrarán a Eros, que heredará precisamente esa 


\section{Arqueología del amor: la representación de Afrodita y de Eros en el pensamiento antiguo.}

doble naturaleza: tanto la idea de 'carencia', de la que ya hablamos antes, como la de 'camino' aparecen en El banquete entre los caracteres constitutivos de Eros.

Otro de los relatos más célebres en el que el dios Eros participa es el de Amor y Psique $^{21}$, que aparece en las Metamorfosis (o El asno de oro) de Apuleyo, novela latina compuesta en el siglo II d. C. La historia de Psique fue repetida frecuentemente entre los autores platónicos y neoplatónicos que entendían el mito como un signo de felicidad eterna en el más allá. Posteriormente fue objeto de muchas interpretaciones relacionadas con el tema del conocimiento. Además, por su significado a la vez alegórico y filosófico, el relato se vincula estrechamente con los mitos de Orfeo y Eurídice y el de Afrodita y Adonis (Martín, 2005).

\section{Comentarios finales}

Finaliza aquí nuestro derrotero por las imágenes y sentidos de los dioses del amor y el erotismo, Afrodita y Eros, que nos propusimos al inicio. Sin duda, el panorama es acotado y, por ende, incompleto. Sin embargo, creemos que se trata de una lectura global del tema del amor, la filosofía y la literatura en el mundo antiguo que pone en relación ideas y representaciones que han tenido, en su momento como en los desarrollos posteriores de la cultura occidental, un impacto indeleble en la conformación ideológica y cultural del amor. No cerramos aquí el debate ni la reflexión, antes bien esperamos que nuestro modesto aporte sea un punto de partida.

\section{Ediciones y traducciones}

Gil, L. (1975). Platón. El banquete. Fedón. Fedro. Barcelona: Labor.

González Iglesias, J. A. (1993). Ovidio. Amores. Arte de amar. Madrid: Cátedra.

Pérez Jiménez, A. (1975). Hesíodo. Teogonía. Trabajos y días. Barcelona: Bruguera.

Publio Ovidio Nasón (2017). Metamorfosis. Recuperado de http://es.wikisource.org/wiki/Portada. Fecha de captura: 18/05/17.

\footnotetext{
${ }^{21}$ Psique simboliza el destino del alma humana, dividida por la atracción que ejercen sobre ella el amor divino y el amor terreno.
} 
Rodríguez Tobal, J. M. (1999). Arte de amar (P. Ovidi Nasonis Ars Amatoria). Edición bilingüe. Madrid: Hiperión.

Segalá y Estalella, L. (trad.). (1982). Homero. Ilíada. Buenos Aires: Hyspamérica.

Segalá y Estalella, L. (trad.). (1982). Homero. Odisea. Buenos Aires: Hyspamérica.

\section{Referencias bibliográficas}

Albano, S. (2004). Michel Foucault. Glosario Epistemológico. Buenos Aires: Quadrata. Alesso, M. (1999). "Itinerarios de Afrodita". Circe, de clásicos y modernos, N 49, 11-40. Alesso, M. (2004). La alegoría en el siglo I. Santa Rosa: Instituto de Estudios Clásicos. Castañares, W. (2014). Historia del pensamiento semiótico. 1. La Antigüedad grecolatina. Madrid: Trotta.

Ciordia, M. J. y L. Funes (comps.) (2012). El amor y la literatura en la Europa bajomedieval y renacentista. Buenos Aires: Colihue.

Curtius, E. R. (1975). Literatura Europea y Edad Media Latina. Vol. I. México: Fondo de Cultura Económica.

Ernout, A. y Meillet, A. (1959). Dictionnaire Étymologique de la Langue Latine (DELL). Histoire des mots. Paris: Klincksiek.

Foucault, M. (2003). Historia de la sexualidad. 2. El uso de los placeres. Buenos Aires: Siglo Veintiuno Editores.

Galán, L. (2005). Eneida. Una introducción crítica. Buenos Aires: Santiago Arcos Editor. Kristeva, J. (1999). Historias de amor. México: Siglo XXI.

Llanos, P. M. (2011). “El adulterio de Marte y Venus en Metamorfosis de Ovidio: relato, narradoras y auditorio internos". Argos, Vol. 34, $\mathrm{N}^{\circ} 2$. Recuperado de http://www.scielo.org.ar/scielo.php?script=sci_arttext\&pid=S1853-

63792011000200003. Fecha de captura: 16/05/17.

Martín, R. (dir.) (2005). Mitología griega y romana. Madrid: Espasa.

Miranda, L. R. (2015). “De Francia con amor: la tradición del amor cortés y la cultura occidental” en L. R. Miranda (ed.). La Edad Media en capítulos. Panorama introductorio a los estudios medievales. Santa Rosa: EdUNLPam, 144-173.

Naughton, V. (2005). Historia del deseo en la época medieval. Buenos Aires: Quadrata. 
Arqueología del amor: la representación de Afrodita y de Eros en el pensamiento antiguo.

Rougemont, D. de (1997). El amor y Occidente. Barcelona: Kairós.

Tola, E. (2005). Ovidio. Metamorfosis. Una introducción crítica. Buenos Aires: Santiago Arcos Editor.

Zimmermann, B. (2003). "Sexualidad y erotismo en la literatura griega". Ordia Prima 2, 155-167. 